\title{
Efek Anti Oksidan Bawang Putih Terhadap Penurunan Bilangan Peroksida Minyak Jelantah
}

\author{
Siti Mardiyah ${ }^{1}$ \\ Prodi D3 Teknologi Laboratorium Medik, FIK, Universitas Muhammadiyah Surabaya \\ ${ }^{1)}$ sitimardiyahfix2@gmail.com
}

\begin{abstract}
Tanggal Submit: 6 Mei 2018

Used cooking oil is leftover cooking oil from food

Tanggal Review: 22 Mei 2018

Tanggal Publish Online:

28 Mei 2018 frying processes. The use of cooking oil which is repeated with a high temperature and a long time can cause the oil to oxidation and hydrolysis, resulting in increased levels of peroxide. High peroxide value can pose a health hazard. Allisin is antioxidants contained in garlic. Allisin are primary antioxidants which act as free radical scavengers that can slow oxidation on used cooking oil. The purpose of this study was to determine the effect of garlic on decreased levels of peroxide in used cooking oil. This type of research is experimental by the number of samples in each treatment as many as 4 samples. Formulation of the problem of this study is whether there is the effect of adding garlic to decreased levels of peroxide on used cooking oil.

From the results of the average levels of peroxide in used cooking oil that has been saved within 3 days is 26.0482 control $\mathrm{mEq}, 10 \mathrm{mEq} \% 23.65098,22.71355 \mathrm{mEq}$ $20 \%, 30 \% \mathrm{mEq} 18.65023,17.92128 \mathrm{mEq} 40 \%, 50 \%$ $16.52508 \mathrm{mEq}$. Statistical analysis with ANOVA test shows the effect of adding garlic to decreased levels of peroxide in used cooking oil with $\mathrm{p}$ value $(\mathrm{sig})=0.000$ which is smaller than 0.05 . The results of Tukey HSD test showed the addition of garlic 30\% is effective to reduce levels of peroxide on used cooking oil.

Therefore, the addition of garlic may inhibit the process of rancidity and lower levels of peroxide in used cooking oil.
\end{abstract}

Keywords: garlic, cooking oil, peroxide value

PENDAHULUAN

Minyak goreng adalah
minyak yang berasal dari lemak
tumbuhan atau hewan yang
dimurnikan dan berbentuk cair

dalam suhu kamar, biasanya digunakan untuk menggoreng makanan. Minyak goreng dari tumbuhan biasanya dihasilkan dari tanaman, seperti kelapa, biji-bijian, 
kacang-kacangan, jagung, kedelai dan kanola. Minyak goreng diperoleh dari hasil tahap akhir proses pemurnian minyak dan terdiri atas beragam jenis senyawa trigliserida. Minyak goreng tersusun oleh berbagai jenis asam lemak jenuh/ tidak jenuh (Kusnandar, 2010).

Dalam teknologi makanan, minyak dan lemak memegang peranan penting. Karena minyak dan lemak memiliki titik didih yang tinggi (sekitar $200^{\circ} \mathrm{C}$ ) maka biasa dipergunakan untuk menggoreng makanan sehingga bahan yang digoreng akan kehilangan sebagian besar air yang dikandungnya dan menjadi kering. Minyak dan lemak juga memberikan rasa gurih spesifik minyak yang lain dari gurihnya protein. Juga minyak memberi aroma yang spesifik (Ramdja dkk, 2010).

Masyarakat Indonesia memiliki kebiasaan menggunakan minyak goreng secara berulang hingga warna minyak goreng pun menjadi berubah coklat sampai kehitaman (minyak Jelantah). Penggunaan minyak goreng secara kontinyu dan berulang-ulang pada suhu tinggi $\left(160-180{ }^{0} \mathrm{C}\right)$ disertai adanya kontak dengan udara dan air pada proses penggorengan akan mengakibatkan terjadinya reaksi degradasi yang komplek dalam minyak dan menghasilkan berbagai senyawa hasil reaksi. Minyak goreng juga mengalami perubahan warna dari kuning menjadi warna gelap. Reaksi degradasi ini menurunkan kualitas minyak dan akhirnya minyak tidak dapat dipakai lagi dan harus dibuang (Maskan dalam Yustinah, 2011).

Alasan penggunaan minyak goreng pada umumnya untuk melakukan penghematan. Apalagi harga minyak goreng tergolong tidak murah bagi sebagian masyarakat tertentu.. Sementara konsumsi makanan gorengan semakin disukai oleh seluruh lapisan masyarakat.

Dengan demikian penanganan dan pemanfaatan minyak goreng harus diketahui dengan benar oleh seluruh lapisan masyarakat (Anonim, 2008).

Berbagai penelitian telah banyak dilakukan oleh para peneliti, yang membuktikan dampak negatif dari minyak goreng yang berulang kali dipakai sampai warnanya hitam 
kecoklatan. Tidak hanya pedagangpedagang kaki lima yang sering menggunakan minyak goreng secara berulang, bahkan dalam dapur keluargapun sering tanpa sadar kita menggunakan minyak goreng secara berulang dengan alasan penghematan. Minyak goreng yang sudah berulangkali dipanaskan akan rusak dan disebut jelantah (Anonim, 2008).

Meskipun dapat digunakan kembali karena alasan ekonomis, namun bila dintinjau dari komposisi kimianya minyak jelantah mengandung senyawa - senyawa yang bersifat karsinogenik selama proses penggorengan. Akibatnya pemakaian minyak jelantah tersebut, dapat merusak kesehatan, ganngguan pencernaan, gatal pada penggorokan, menimbulkan penyakit kanker, dan dapat mengurangi kecerdasan generasi berikutnya. Karena jelantah itu mudah mengalami oksidasi, maka jika disimpan akan cepat berbau tengik. Selain itu, dalam minyak jelantah juga dapat digunakan oleh jamur aflatoksin sebagai tempat berkembang biak jamur ini menghasilkan racun aflatoksin yang dapat menyebabkan berbagai penyakit, terutama pada hati atau liver(Mutiara, 2007).

Pemanasan yang terlalu tinggi menyebabkan sebagian minyak teroksidasi dan minyak yang terdapat dalam suatu bahan, dalam keadaan panas akan mengekstraksi zat warna yang terdapat dalam bahan tersebut. Proses oksidasi dapat berlangsung bila terjadi kontak antara sejumlah oksigen dengan minyak atau lemak. Terjadinya reaksi oksidasi ini dapat mengakibatkan bau tengik pada minyak dan lemak. Oksidasi biasanya dimulai dengan pembentukan peroksida dan hidroperoksida (Ketaren, 1986).

Bilangan peroksida pada minyak jelantah dapat di hambat dengan cara menambahkan antioksidan.

Antioksidan adalah zat yang dapat menunda atau mencegah terjadinya reaksi antioksidasi radikal bebas dalam oksidasi lemak. Zat antioksidan yang dikenal ada 2 yaitu antioksidan alami dan antioksidan sintetik (Rohman, 2013).

Antioksidan sintetik adalah antioksidan yang diperoleh dari hasil sintesa reaaksi kimia seperti 
butylated hydroxyanisole (BHA), butylated hydroxytoluene (BHT), tert-butyl hydroquinone (TBHQ), dan propyl gallat. Antioksidan sintetik lebih sering digunakan sebagai antioksidan minyak goreng karena tergolong murah dan cukup efektif untuk di gunakan sebagai antioksidan. Namun dewasa ini pemakaian antioksidan sintetis mulai mendapat respon negatif karena berpotensi menyebabkan kanker dalam tubuh. Oleh karena itu, penggunaan antioksidan alami sebagai pengganti semakin diminati karena dipercaya lebih aman untuk kesehatan (Ayucitra dkk, 2011).

Antioksidan alami adalah antioksidan yang diperoleh langsung dari alam. Salah satunya yaitu bawang putih. Bawang putih adalah salah satu bahan yang paling umum digunakan sebagai penyedap makanan selain itu bawang putih juga dipakai sebagai antioksidan dan antimikroorganisme. Bawang putih juga memiliki banyak manfaat, bukan hanya sebagai antibakteri, antivirus, antijamur, antiprotozoal, tetapi juga memiliki efek menguntungkan pada sistem kardiovaskuler dan kekebalan tubuh.
Aktivitas antimikroba bawang putih berasal dari senyawa organosulfur. Selain efek antimikroorganisme, bawang putih menunjukkan aktivitas antioksidan yang efektif secara in vivo dan in vitro(Ankri \& Mirelman, 1999)

Hasil penelitian Astuti (2013) melaporkan bahwa ada pengaruh lama penambahan bawang putih dalam minyak goreng bekas pakai terhadap penurunan bilangan peroksida. Nilai prosentase penurunan bilangan peroksida berdasarkan lama penambahan bawang putih selama 1, 2, 3, dan 4 jam berturut-turut yaitu $11,18 \%$; $55,27 \% ; \quad 55,36 \% ; \quad 100,00 \%$. Pengaruh lama penambahan bawang putih dalam minyak goreng bekas pakai terhadap bilangan peroksida sangat kuat yaitu sebesar $78,4 \%$ dan $21,6 \%$ dipengaruhi oleh factor lain

Bawang putih mengandung komponen yang bersifat antibiotik, antioksidan, antikanker, antiparasit, sehingga antioksidan dapat digunakan untuk penurunan bilangan peroksida. Pada saat bawang bawang putih dimemarkan atau dihaluskan, zat alisin yang sebenarnya tidak berbau akan terurai. Dengan 
dorongan enzim alinase, aliin terpecah menjadi alisin, amonia, dan asam piruvat. Bau tajam alisin disebabkan karena kandungan zat belerang. Aroma khas ini menyengat ketika zat blerang (sulfur) dalam alisin diterbangkan ammonia ke udara, sebab ammonia mudah menguap. Pada saat bawang putih di iris atau bubuk bawang putih kering dilarutkan dalam larutan non asam, maka L-sistein sulfoksida akan berubah menjadi tiosulfinat yang merupakan komponen aroma bawang putih segar (Ankri \& Mirelman, 1999).

Selain alisin, bawang putih juga memiliki senyawa alil yang berkhasiat obat. Senyawa alilpaling banyak terdapat dalam bentuk dialiltrisulfida. Kandungan antioksidan lain pada bawang putih adalah senyawa fenol, khususnya aliksin, N-fruktosil glutamat, Nfruktosil arginin dan selenium.

Senyawa fenol merupakan salah satu konstituen yang mampu menghambat atau menghentikan reaksi oksidasi berantai. Aliksin merupakan senyawa aktif dari aliin yang terbentuk oleh enzim allinase ketika bawang putih di potong.
Produk degradasi lainnya dari aliin adalah ajoene yang dapat menghambat sintesis enzim siklooksigenase dan lipoksigenase. Selenium dalam bawang putih berperan aktif sebagai antioksidan dan merupakan bagian dari enzim gluthione peroksidase.

Berdasarkan latar belakang dan permasalahan di atas maka rumusan masalah penelitian ini adalah "Apakah ada pengaruh penambahan bawang putih terhadap penurunan kadar bilangan peroksida pada minyak jelantah". Tujuan umum penelitian adalah mengetahui pengaruh penambahan bawang putih terhadap penurunan bilangan peroksida pada minyak jelantah dan tujuan khususnya adalah : (1)Mengidentifikasi bilangan peroksida pada minyak jelantah tanpa penambahan bawang putih, (2)Mengidentifikasi bilangan peroksida pada minyak jelantah yang ditambahkan dengan bawang putih.

\section{METODE PENELITIAN}

Jenis penelitian ini adalah eksperimental dengan tujuan untuk mengetahui pengaruh penambahan bawang putih terhadap penurunan 
kadar bilangan peroksida pada

minyak jelantah.

Populasi penelitian ini adalah minyak jelantah yang diambil dari pedagang penyetan di sekitar jalan Sutorejo Surabaya. Sampel penelitian ini adalah minyak jelantah yang diambil dari 4 pedagang penyetan di sekitar jalan Sutorejo Surabaya dengan cara Purposive sampling. Besar sampel ditetapkan berjumlah 4 sampel pada setiap perlakukan konsentrasi penambahan bawang putih.

$$
\text { Variabel bebas dalam }
$$
penelitian ini adalah kosentrasi penambahan bawang putih yang dikategorikan menjadi $0 \%, 10 \%, 20 \%, 30 \% \quad 40 \%$ dan $50 \%$. Sedangkan Variabel terikat adalah bilangan peroksida yang dinyatakan dengan satuan mEq. Variabel Kontrol adalah waktu, jenis minyak, dan suhu.

Uji laboratorik bilangan peroksida pada sampel minyak jelantah dilakukan di laboratorium kimia Universitas Muhammadiyah Surabaya.

Teknik pengumpulan data dilakukan dengan cara observasi atau pengamatan melalui pengujian laboratorium. Pengujian bilangan peroksida pada minyak jelantah secara laboratorik dilakukan dengan metode iodometri. Langkah pengujian laboratorik bilangan peroksida minyak jelantah sebagai berikut :

\section{Prinsip pemeriksaan:}

Pengukuran sejumlah iod yang di bebaskan dari KI $10 \%$ melalui oksidasi oleh peroksida dalam lemak atau minyak pada suhu ruang dalam pelarut asam asetat dan kloroform.

\section{Alat dan Bahan}

Alat yang digunakan yaitu Erlenmeyer bertutup asa $250 \mathrm{ml}$, buret, labu ukur, beaker glass, pipet volume, waterbath, termometer, mortal, batang pengaduk, oven, corong. Bahan utama yang digunakan antara lain : Minyak Goreng Bekas Pakai yang didapat dari Pedagang gorengan di daerah Sutorejo Surabaya, Bawang Putih Sebagai Antioksidan Alami. Bahan yang digunakan untuk analisis antara lain : $\mathrm{NaOH} 0,1 \mathrm{~N}$, Asam oksalat 0,1 $\mathrm{N}$, Indikator PP $1 \%$, Alkohol 96\% netral.

\section{Perlakuan Sampel}

Sampel minyak goreng yang diperoleh dari pedagang penyetan 
dikelompokkan menjadi 5 kelompok

perlakuan sebagai berikut :

1) Tanpa penambahan bawang putih

Memipet minyak $100 \mathrm{ml}$ kemudian masukkan dalam beaker glass dan simpan pada suhu kamar selama 3 hari

2) Penambahan bawang putih 10 $\%$

Menimbang 10 gram bawang putih kemudian dilarutkan dalam 100 ml minyak kemudian simpan pada suhu kamar selama 3 hari

3) Penambahan bawang putih 20 $\%$

Menimbang 20 gram bawang putih kemudian dilarutkan dalam 100 ml minyak kemudian simpan pada suhu kamar selama 3 hari

4) Penambahan bawang putih 30 $\%$

Menimbang 30 gram bawang putih kemudian dilarutkan dalam 100 ml minyak kemudian simpan pada suhu kamar selama 3 hari

5) Penambahan bawang putih 40 $\%$
Menimbang 40 gram bawang putih kemudian dilarutkan dalam $100 \mathrm{ml}$ minyak kemudian simpan pada suhu kamar selama 3 hari

6) Penambahan bawang putih 50 $\%$

Menimbang 50 gram bawang putih kemudian dilarutkan dalam 100 ml minyak kemudian simpan pada suhu kamar selama 3 hari

\section{Standarisasi $\mathrm{Na}_{2} \mathrm{~S}_{2} \mathrm{O}_{3} \mathrm{O} .1 \mathrm{~N}$ dengan $\mathrm{KIO}_{3} \mathrm{O} .1 \mathrm{~N}$}

Standarisasi dilakukan untuk membakukan konsentrasi larutan $\mathrm{Na}_{2} \mathrm{~S}_{2} \mathrm{O}_{3}$ yang akan digunakan dalam penetapan bilangan peroksida. Larutan natrium tiosulfat distandarisasi dengan larutan $\mathrm{KIO}_{3}$ $0,1 \mathrm{~N}$ secara iodometri sebagai berikut :

MePipet $10 \mathrm{ml}$ larutan standart $\mathrm{KIO}_{3}$ O.1 N kemudian masukkan ke dalam labu iod 250. Lalu ditambahkan 10 ml KI $10 \%$ dan $10 \mathrm{ml} \mathrm{H}_{2} \mathrm{SO}_{4} 2 \mathrm{~N}$. Selanjutnyan elemeyer ditutup dan didiamkan di tempat gelap hingga terbentuk warna coklat selama 10 menit. Kemudian dilakukan titrasi dengan $\quad \mathrm{Na}_{2} \mathrm{~S}_{2} \mathrm{O}_{3} \quad 0.1 \quad \mathrm{~N}$ sampai warna coklat menjadi kuning muda. Titrasi dihentikan sejenak dan pada 
elemeyer ditambahkan indikator

amilum 1\% 0,5 ml. Ttitrasi kembali

dilakukan sampai warna biru tepat hilang.

\section{Penentuan Bilangan Peroksida (SNI, 1992)}

Penentuan

bilangan

peroksida dilakukan secara bergantian pada seluruh sampel minyak goreng sebagai berikut :

$\begin{array}{rrrr}\text { Menimbanng } 10 & \text { gram } \\ \text { sampel minyak goreng } & \text { dalam }\end{array}$ erlenmeyer $300 \mathrm{ml}$ bertutup asa. Kemudian ditambahkan dengan 100 ml larutan Alkohol Benzene 1:1. Selanjutnya menambahkan 1 gram KI yang sebelumnya di larutkan dengan $5 \mathrm{ml}$ asam sulfat. Kemudian semua bahan diaduk hingga homogendan didiamkan pada tempat gelap selama $1 / 2$ jam. Setelah proses tersebut ditambahakan larutan kanji kanji $1 \mathrm{ml}$ sebagai indicator. Tahap selanjutnya adalah mentritasi sampel yang telah diperlakukan diatas dengan Natrium Thio Sulfat $0,01 \mathrm{~N}$ sampai warna biru tepat hilang.

Berdasarkan hasil uji iodometri, bilangan peroksida dihitng dengan rumus :

\section{Teknik Analisis Data}

Data bilangan peroksida dari hasil pemeriksaan laboratrik selanjutnya diuji dengan serangkaian uji statistik. Langkah awal adalah menguji homogenitas data yaitu uji untuk menentukan normal / tidak normalnya data. Jika normal maka akan dilanjutkan dengan uji Anova dan di teruskan dengan uji Tukey HSD yang bertujuan untuk mengetahui konsentrasi yang efektif untuk menghambat angka peroksida. Tetapi, jika data berdistribusi tidak normal maka data tersebut di uji dengan Kruskal-Wallis dengan tujuan untuk mengetahui pengaruh penambahan bawang putih terhadap bilangan peroksida pada minyak jelantah dan di lanjutkan uji ManWhitney untuk menentukan perlakuan yang efektif (A. Aziz Alimul H, 2010). 


\section{HASIL DAN PEMBAHASAN}

Setelah

dilakukan

uji

laboratorik bilangan peroksida dengan menggunakan metode iodometri terhadap sampel minyak goreng jelantah, maka diperoleh hasil penelitian sebagai berikut:

Tabel 3.1 Kadar Bilangan Peroksida berdasarkan konsentrasi penambahan bawang putih

\begin{tabular}{|c|c|c|c|c|c|c|}
\hline \multirow{2}{*}{$\begin{array}{c}\text { Kode } \\
\text { Sampel }\end{array}$} & \multicolumn{5}{|c|}{ Kadar Bilangan Peroksida } \\
\cline { 2 - 7 } & Kontrol & $\mathbf{1 0 \%}$ & $\mathbf{2 0} \%$ & $\mathbf{3 0 \%}$ & $\mathbf{4 0} \%$ & $\mathbf{5 0 \%}$ \\
\hline 1 & 26.7 & 24.2 & 22,9 & 18,8 & 17.5 & 17.1 \\
\hline 2 & 25.8 & 23.7 & 22.9 & 17.5 & 17.1 & 16.3 \\
\hline 3 & 25.4 & 23.3 & 22.5 & 18.8 & 18.3 & 17.5 \\
\hline 4 & 26.3 & 23.3 & 22.5 & 20.0 & 18.7 & 15.3 \\
\hline Jumlah & 104.2 & 94.6 & 90.8 & 74.6 & 71.7 & 66.1 \\
\hline $\begin{array}{c}\text { Rata - } \\
\text { Rata }\end{array}$ & 26.04 & 23.6 & 22.7 & $\begin{array}{c}18.6 \\
5\end{array}$ & 17.92 & 16.5 \\
\hline $\begin{array}{c}\text { Std } \\
\text { Deviasi }\end{array}$ & 0.538 & 0.39 & 0.24 & $\begin{array}{c}1.04 \\
1\end{array}$ & 0.760 & 0.99 \\
\hline
\end{tabular}

Berdasarkan tabel 3.1 nilai rata-rata bilangan peroksida pada minyak jelantah berdasarkan penambahan konsentrasi bawang putih tanpa penambahan (0\%); 10\%, $20 \%, 30 \%, 40 \%, 50 \%$ berturut adalah $26.6743 \mathrm{mEq}$,. $23.6 \mathrm{mEq}$; $22,7 \% \mathrm{mEq} ; 18,65 \% \mathrm{mEq}, \quad 17,92$ $\mathrm{mEq}$ dan $16,5 \% \mathrm{mEq}$. Nilai rata-rata diatas menjukkan bahwa kadar peroksida terbesar terjadi sebelum penambahan bawang putih, sedangkan nilai rata-rata peroksida terkecil terjadi pada penambahan bawang putih $50 \%$.
Nilai rerata bilangan peroksida pada tabel 3.1 dapat digambarkan dalam bentuk diagram batang berikut :

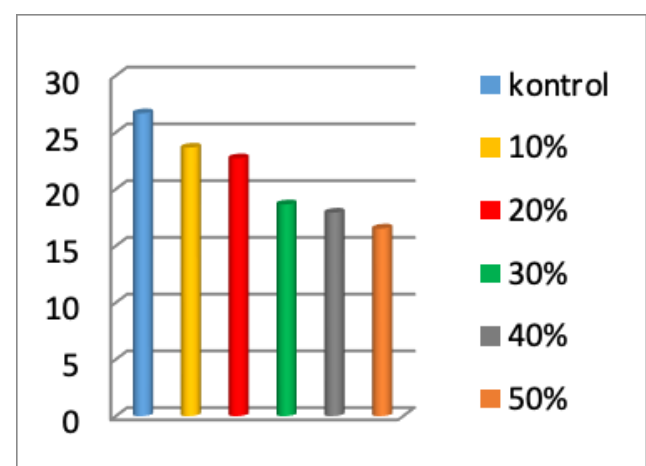

Gambar 3.1. Diagram batang rerata bilangan peroksida minyak jelantah

\section{Analisis Data}

Hasil uji statistik terhadap data laboratorik bilangan peroksida pada minyak jelantahmenunjukkan hasil sebagai berikut : Hasil uji normalitas menggunakan uji one-Sample kolmogorov-Smirnov Test. Diperoleh bahawa data laboratorik tersebut terdistribusi normal dengan nilai signifikansi $\mathrm{P}>0$. Hasil Uji normalitas data memenuhi persyaratan uji selanjutnya untuk menentukan pengaruh penambahan bawang putih pada penurunan kadar bilangan peroksida pada minyak jelantah menggunakan uji Anova.

Berdasarkan hasil uji ANOVA menunjukkan bahwa ada pengaruh penambahan bawang putih terhadap kadar bilangan peroksida pada 
minyak jelantah yang ditunjukkan dengan nilai $\mathrm{F}$ hitung sebesar 107.046dengan taraf signifikan $(\mathrm{P})$ 0,000 dimana lebih kecil dari 0,05 Jadi, Hipotesis alternatif $\left(\mathrm{H}_{1}\right)$ diterima.

Untuk mengetahui lebih lanjut sejauh mana pengaruh konsentrasi penambahan bawang putih pada minyak jelantah dilakukan dengan uji Tukey HSD dengan menggunakan program SPSS (Statistical Program social Saince) 17,0 Hasil uji Tukey terhadap data laboratorik bilangan peroksida pada konsentrasi 0\%, 10\%,20\%, 30\%, dan $40 \%$ menunjukkan adanya perbedaan siginifikan dengan taraf signifikan $\mathrm{P}<0$. Sementara pada konsentrasi $40 \%$ dan $50 \%$ nilai signifikansi $\quad \mathrm{P}>0$ artinya tidak berbeda signif

Hasil uji laboratorik bilangan peroksida menujukkan bahwa ratarata bilangan peroksida tertinggi pada minyak jelantah yaitu sebesar $26.0482 \mathrm{mEq}$, yakni pada konsetrasi 0\% (tanpa penambahan) bawang putih dan bilagan peroksida terendah pada minyak jelantah yaitu sebesar $16.52508 \mathrm{mEq}$. Hasil rata-rata bilangan peroksida ini menjelaskan bahwa perbedaan konsentrasi menyebabkan perbedaan bilangan peroksida pada minyak jelantah. Semakin tinggi konsentrasi penambahan bawang putih semakin menurunkan bilangan peroksida pada minyak jelantah.

Berdasarkan hasil uji statistik, data laboratorik bilangan peroksida yang telah teruji berdistribusi normal, dilanjutkan dengan melakukan uji anova. Uji anova ini menguji signifikansi pengaruh perbedaan konsentrasi penambahan bawang putih terhadap nilai rerata hasil uji laboratorik bilangan peroksida minyak jelantah.

Hasil uji anova diperoleh nilai $\mathrm{F}=107.046$ dengan nilai signifikan 0,000 yang dimana nilainya $<0,05$ yang berarti ada pengaruh signifikan penambahan bawang putih terhadap kadar bilangan peroksida pada minyak jelantah. Hal ini menunjukkan bahwa perbedaan konsentrasi penambahan bawang putih memberikan pengaruh signifikan terhadap bilangan peroksida minyak jelantah. Untuk menguji sejauhma na pengaruh masing-masing konsentrasi bawang putih terhadap konsentrasi yang lain 
dilakukan dengan menggunakan uji

Tukey HSD. Berdasarkan hasil uji

Tukey HSD variasi penambahan bawang putih pada konsentrasi $40 \%$, $50 \%$ tidak memiliki perbedaan yang signifikan. Sehingga pengaruh penambahan bawang putih terhadap kadar bilangan peroksida pada minyak jelantah mulai efektif dari konsentrasi $30 \%$.

Kadar bilangan peroksida dapat turun disebabkan oleh kandungan antioksidan yang terdapat pada bawang putih. Antioksidan yang terdapat pada bawang putih yaitu alisin. Alisin, zat aktif yang mempunyai sifat anti bakteri yang dapat menghambat outooksidasi dan menghambat bilangan peroksida meningkat.

Bawang putih mempunyai sifat antioksidan karena bawang putih mengandung senyawa allisin yang menurut Sudarmaji (2012) bahwa senyawa alisin ini adalah senyawa yang efektif menghambat proses autooksidasi lemak tidak jenuh sehingga dapat mencegah ketengikan minyak goreng dan dapat menambah waktu penyimpanan dari minyak goreng tersebut. Senyawa ini mengakibatkan terhambatnya oksidasi lebih lanjut pada minyak goreng.

Jadi semakin besar penambahan bawang putih pada minyak jelantah maka semakin besar pula antioksidan pada minyak jelantah tersebut sehingga penurunan kadar bilangan peroksida pada minyak jelantah akan semakin besar. Hal ini dikarena antioksidan tersebut mampumemberikan atom hidrogen secara cepat ke radikal lemak atau mengubahnya ke bentuk lebih stabil, sementara turunan radikal antioksidan tersebut memiliki keadaan lebih stabil dibanding radikal lemak.

\section{KESIMPULAN}

Berdasarkan penelitian ini, dapat disimpulkan sebagai berikut :

Ada pengaruh signifikan penambahan bawang putih terhadap kadar bilangan peroksida pada minyak jelantah dengan nilai $\mathrm{p}=(\mathrm{p}$ $<0,05)$,dikarenakan bawang putih mengandung allisin. Efek anti oksidan efektif mulai terjadi pada konsentrasi $30 \%$. 


\section{DAFTAR PUSTAKA}

Ankri S, Mirelman D. Antimicrobial properties of allicin from garlic. Microbes and Infection. 1999;1:125-129.

Anonim. (2008). Mengenal Minyak Goreng Sehat. Tersedia di http://www.jawaban.com/news /health/detail.php?id_news $=07$ 1120194053 \&off $=0$

Budianto, A.K,2009,Dasar-dasar Ilmu Gizi,Malang : UMM Press

Cairns, Donald. 2008. Intisari Kimia Farmasi. edisi 2. Buku Kedokteran EGC 1655. Jakarta

Chairunisa. 2013. Uji Kualitas Minyak Goreng pada Pedagang Gorengan di Sekitar Kampus UIN Syarif Hidayatullah Jakarta. Jakarta: Fakultas Kedokteran dan Ilmu Kesehatan UIN Syarif Hidayatullah

Djatmiko dan Widjaja. 1973. http://.wikipedia.org/Minyak goreng.com Diakses tanggal 5 Mei 2012.

Fessenden. 1986. Minyak dan lemak?.http://google.com/miny ak-bekas/ . Diakses tanggal 11 Mei 2012.

file:///H:/bab2/fungsiminyak.htm

Graha, Chairinniza K. 2010. 100 Questions \& Answers: Kolesterol. Jakarta:PT Elex Media Komputindo Kelompok Gramedia
Hala, Yusminah. 2013. Penentuan Bilangan Peroksida dan Asam Lemak Bebas pada Minyak Goreng Asal Sulawesi dengan Penambahan Antioksidan Alami. Makassar: Universitas Negeri Makassar

http://www.wedaran.com/18201/ma nfaat-bawang-putih-bagikesehatan-dan-efeksampingnya/2000

http://www.eBookPangan.com/2006/ khasiat-dan-pengolahanbawang/

http://www.skripsitesis.com/09/26/pengaruhlama-penyimpanan-minyakkelapa-terhadap-angkaperoksida-dari-papua-tahun2009-pdf-doc.htm). diakses tanggal 11 Mei 2012

http://repository.usu.ac.id/bitstream/ 123456789/1320/1/tkimia-

Netti.pdf. diakses tanggal 23 April 2012.

http://repository.usu.ac.id/bitstream/ 123456789/20973/4/ChapterII. pdf. diakses tanggal 23 April 2012.

http//definisiminyak.htm

http://www.//Wikipedia.com//.Diaks es tanggal 6 Mei 2012.

Kusnandar, Feri. 2010. Kimia Pangan: Komponen Makro. Jakarta: Dian Rakyat

Ketaren. 1989. Pengantar Teknologi Minyak dan Lemak Pangan. Cetakan Pertama. Jakarta : UIPress. 
Ketaren,S.2005.Minyak Dan Lemak Pangan.Jakarta;Penerbit Universitas Indonesia. Halaman 284

Rahmawati, Reny.2012.Keampuhan bawang putih tunggal (bawang lanang).Yogyakarta. Pustaka Baru Press.

Rohman, Abdul dan Sumantri. 2007. Analisis Makanan. Gadjah Mada University Press, Yogyakarta.

Rohman, Abdul. 2013. Analisi Komponen Makanan. Yogyakarta: Graha Ilmu

Sitepoe, Mangku. 2008. Corat-Coret Anak Desa Berprofesi Ganda. Jakarta: KPG (Kepustakaan Populer Gramedia)

Sudarmadji, S., Bambang, H., dan Suhardi. 1981. Prosedur Analisa untuk Bahan Makanan dan Pertanian. Yogyakarta: Liberty Yogyakarta

Tapan MHA, Erik. 2005. Kanker, Antioksidan, dan Terapi Komplementer. Jakarta:PT Elex Media Komputindo Kelompok Gramedia

Winarno, F. G. 1992. Kimia Pangan dan Gizi. PT Gramedia Pustaka Utama. Jakarta.

Winarno, F.G. 1999. Minyak Goreng Dalam Mепи Masyarakat. Pusbangtepa IPB.Bogor.

Winarsi, Hery. 2007. Antioksidan Alami dan Radikal Bebas. Yogyakarta: Kanisius
Ramdja, A. Fuadi., Lisa F., Daniel K. 2010. Pemurnian Minyak Jelantah Menggunakan Ampas Tebu sebagai Adsorben. Jurnal Teknik Kimia: Vol. 17 No. 1

Yustinah. 2011. Adsorbsi Minyak Goreng Bekas Menggunakan Arang Aktif dari Sabut Kelapa. Jakarta: Universitas Muhammadiyah Jakarta 